\title{
Use of Modified Diethylamine Phosphorus-containing Polymer for Solid Phase Extraction of Cobalt and Lead in Fruit Samples Employing Flame Atomic Absorption Spectrometry
}

\author{
Nusrat Jalbania $^{\mathrm{a}, \mathrm{b}}$, R.M. Alosmanov ${ }^{\mathrm{c}}$, and Mustafa Soylak*a \\ ${ }^{\text {a }}$ Erciyes University, Fen Faculty, Department of Chemistry, 38039 Kayseri, Turkey \\ b PCSIR Laboratories, Karachi, Pakistan \\ ${ }^{\mathrm{c}}$ Baku State University, Chemistry Department, Z.Khalilov str., 23, Baku, AZ1148 Azerbaijan
}

\section{INTRODUCTION}

Some metals such as cobalt are necessary for humans, animals, and plants while other metals such as lead are toxic. These metals are found in the environment (foods, plants, air, and water) due to anthropogenic activity and contamination during industrial processes, preservation, and cooking (1-7). These elements can be very harmful to humans and animals even at low concentrations when ingested over a long period of time $(8,9)$. There is a relationship between long-term effects on health and the presence of these metals in foods (10). Thus, it becomes essential that they are kept at acceptable and safe levels because they can create clinical problems for human health (11-15).

The determination of metal ions at trace levels by flame atomic absorption spectrometry (FAAS) has several advantages such as high selectivity, speed, and fairly low operational cost. However, the direct determination of trace elements at extremely low concentrations is often very difficult due to insufficient sensitivity of the methods and matrix interferences (1618).

Several separation and preconcentration methods such as cloud point extraction, liquid-liquid microextraction, coprecipitation, flotation, and solid phase extraction (SPE) have been widely used (19-

*Corresponding author.

E-mail: soylak@erciyes.edu.tr

Tel./Fax: +90 3524374933

\begin{abstract}
A solid phase extraction (SPE) method was developed using 1-(2-thiazolylazo)-2-naphthol (TAN) as a chelating reagent and a modified diethylamine phosphorus-containing polymer (DPCP) as the adsorbent which was loaded into the column for preconcentration of trace amounts of cobalt and lead in fresh fruit samples. A preliminary experiment was carried out at $\mathrm{pH}$ 6.0, which is best suited for optimization and accumulation of the metal ions from the column. After phase separation/elution, the enriched analytes in the final solution were determined by flame atomic absorption spectrometry (FAAS). Interfering ions were also studied which were found not to have any significant interference effect on the \% recovery of the metals ions. A preconcentration factor of 10 was obtained. The detection limits for the fresh fruit samples were $4.4 \mu \mathrm{g} \mathrm{L}^{-1}$ for Co and $1.04 \mu \mathrm{g} \mathrm{L}^{-1}$ for $\mathrm{Pb}$. Validation of the developed method was performed using standard reference material SRM 1515 Apple Leaves. The proposed procedure is simple, precise, accurate, and inexpensive.
\end{abstract}

20) for the separation and preconcentration of the metal ions at trace levels. The SPE method is simple, economical, and requires a minimum amount of organic solvents $(21,22)$.
In this study, a solid phase extraction (SPE) method was developed using a diethylamine phosphorus-containing polymer (DPCP) for the preconcentration and separation of trace amounts of lead and cobalt as 1-(2-thiazolylazo)2-naphthol (TAN) chelates. The method was applied to the determination of lead and cobalt in fruit samples.

\section{EXPERIMENTAL}

\section{Instrumentation}

The absorbance measurements were performed using a PerkinElmer ${ }^{\circledR}$ Model 3110 flame atomic absorption spectrometer (FAAS) (PerkinElmer, Inc., Shelton, CT, USA), equipped with an airacetylene flame and a hollow cathode lamp. The operating parameters are listed in Table I.

A model Nel pH 900 digital pH meter (Nel A.S., Ankara, Turkey), equipped with a combined glass electrode, was used for the $\mathrm{pH}$ adjustments. All solutions were passed into a column packed with a DPCP phosphate-containing polymer adsorbent.

\section{Table I}

FAAS Instrumental Operating Parameters for $\mathrm{Pb}$ and Co Determination

\begin{tabular}{lll}
\hline Element & $\mathrm{Pb}$ & $\mathrm{Co}$ \\
Wavelength (nm) & 283.3 & 240.7 \\
Slit Width (nm) & 0.7 & 0.2 \\
Lamp Current (mA) & 15 & 30 \\
\hline
\end{tabular}


Reagents, Standard Solutions, and Glassware

Analytical grades of nitric acid (65\%) and reagents (E. Merck, Darmstadt, Germany) were used. During the experimental work, ultra-pure water was used (Millipore ${ }^{\circledR}$ Milli-Q ${ }^{\circledR}$ system $18 \mathrm{M} \Omega$ $\mathrm{cm}^{-1}$ resistivity, Millipore, Bedford, MA, USA). Stock solutions containing $1000 \mathrm{mg} \mathrm{L}^{-1}$ of lead and cobalt were separately prepared from lead nitrate and cobalt nitrate (Aldrich, Milwaukee, WI, USA), respectively, and placed into $1 \mathrm{~L}$ calibrated flasks with $1 \%$ of $\mathrm{HNO}_{3}$. Dilute standard solutions and model solutions were prepared daily from the stock solutions.

Diethylamine-modified phosphorus-containing polymer (DPCP) was used as a solid phase extractor and prepared according to the literature (23). A 5\% solution of polybutadiene in $\mathrm{CCl}_{4}$ was subjected to oxidative chlorophosphorylation by $\mathrm{PCl}_{3}$ under the action of oxygen. This resulted in the formation of a modified substance of three-dimensional structure containing functional groups with $\mathrm{P}-\mathrm{Cl}$ bonds, which were further processed with water for hydrolysis. The adsorbent was purified and dried at $50{ }^{\circ} \mathrm{C}$ in a vacuum cabinet (23).

For $\mathrm{pH}$ adjustment, a phosphate buffer of pH 6.0 was prepared by adding an appropriate amount of sodium dihydrogen phosphate and disodium hydrogen phosphate.

A $0.1 \%(\mathrm{w} / \mathrm{v})$ chelating agent 1-(2-thiazolylazo)-2-naphthol (TAN) was purchased from Merck, Darmstadt, Germany, and prepared daily in ethanol/water (1/1 v/v). For validation of the method, a standard reference material SRM NIST 1515 Apple Leaves (National Institute for Standards and Technology, Gaithersburg, MD, USA) was used.

\section{Preconcentration Procedure}

Four mL of buffer solution (to give the desired $\mathrm{pH}$ between 3-8) and $500 \mu \mathrm{L}$ of $0.1 \%$ TAN solution were added to a 30-mL standard solution containing $20 \mu \mathrm{g}$ lead and $10 \mu \mathrm{g}$ cobalt. The metal-TAN solution was passed through the col-

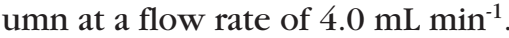
Then, the adsorbed metal chelate on the column was eluted with a 10 -mL portion of $3.0 \mathrm{~mol} \mathrm{~L}^{-1} \mathrm{HNO}_{3}$. The eluent was analyzed for the FAAS determination of cobalt and lead concentrations.

\section{Analysis of Fresh Fruit Samples}

The proposed method was applied for the analysis of fresh fruit samples. The samples were collected in 2013 from markets located in Kayseri City, Turkey. The samples were first washed with tap water, then twice with distilled water. Then they were washed with ultrapure water, cut, oven-dried at $90^{\circ} \mathrm{C}$ for 24 hours, and homogenized by using an agate mortar and pestle. A $1000 \mathrm{mg}$ amount of each sample was taken into a $100-\mathrm{mL}$ glass, treated with $10 \mathrm{~mL}$ of $\mathrm{HNO}_{3}(65 \%)$ and $5 \mathrm{~mL}$ of $\mathrm{H}_{2} \mathrm{O}_{2}(35 \%)$, and evaporated to near dryness. After cooling to room temperature, the resulting mixture was filtered through a blue band filter paper (Advantec Toyo, Japan) and diluted to $10 \mathrm{~mL}$ with distilled water. The $\mathrm{pH}$ of each sample was properly adjusted to 6.0 by addition of $4 \mathrm{~mL}$ of phosphate buffer solu- tion and then $500 \mu \mathrm{L}$ TAN solution. This solution (of $14.5 \mathrm{~mL}$ volume) was passed through the column at a flow rate of $4.0 \mathrm{~mL} \mathrm{~min}{ }^{-1}$. Then, the adsorbed metal chelate on the column was eluted with a $10-\mathrm{mL}$ portion of $3.0 \mathrm{~mol} \mathrm{~L}^{-1} \mathrm{HNO}_{3}$. The analyte concentration in the eluent solutions were determined by FAAS. The blanks were treated in the same manner as the samples but without analyte.

\section{RESULTS AND DISCUSSION}

\section{Optimization Strategy}

In order to obtain quantitative recoveries, the effects of some analytical parameters including $\mathrm{pH}$, ligand volume, eluent concentration, and eluent volume were optimized. The influences of some IA and IIA group elements, some transition metals, and some anions on the recovery of the analytes were also examined.

\section{Influences of $\mathbf{p H}$}

In the present study, the $\mathrm{pH}$ plays a key role in obtaining the quantitative recovery of the metal ions in the solid phase extraction studies (24-27). The effects of $\mathrm{pH}$ on the recovery of cobalt and lead on diethylamine-modified phosphorus-containing polymer (DPCP) were investigated in the $\mathrm{pH}$ range of 3.0-8.0. The quantitative recovery for $\mathrm{Co}$ and $\mathrm{Pb}$ was achieved at pH 6.0 (Figure 1). Hence, all further studies were carried out at $\mathrm{pH} 6.0$ using the phosphate buffer.

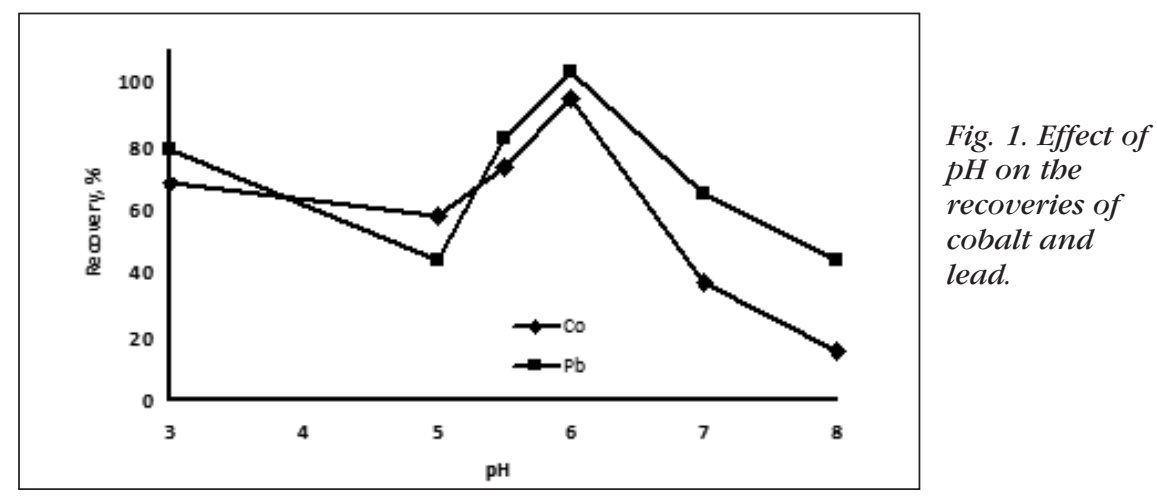




\section{Influence of Ligand Volume}

The effect of ligand volume is also an important factor in this study. The experimental results showed that the \% recovery of the metal ions decreased at the beginning and then increased with an increase in ligand volume (Figure 2). Quantitative recoveries were obtained at $500 \mu \mathrm{L}$ of ligand volume which was chosen as the optimal value for this study.

\section{Influence of Sample Volume}

In solid phase extraction studies, sample volume is a critical parameter for the quantitative recovery of the analytes (28-30). The sample volume was examined to optimize the recovery of the analyte ions (see Figure 3). Quantitative recoveries were obtained in the sample volume ranging from $25-100 \mathrm{~mL}$. The preconcentration factor was 10 with a sample volume of $100 \mathrm{~mL}$ and an eluent volume of $10 \mathrm{~mL}$.

\section{Eluent Type/Eluent Volume}

Four types of eluent (1.0 and $3.0 \mathrm{~mol} \mathrm{~L}^{-1}$ nitric acid and hydrochloric acid) were examined to obtain quantitative recoveries of the analyte metal ions. The analyte ions were quantitatively recovered with $3.0 \mathrm{~mol} \mathrm{~L}^{-1}$ nitric acid.

\section{Flow Rates}

The effect of different flow rates of the sample solution and the eluent solution on the recovery of the analytes was studied at flow rates from 1.0 to $10.0 \mathrm{~mL} \mathrm{~min}{ }^{-1}$ under constant optimal conditions. The recovery of the analytes was quantitative at a flow rate of $4.0 \mathrm{~mL} \mathrm{~min}^{-1}$ or less for both the sample solution and the eluent solution. All subsequent work was carried out at a flow rate of $4.0 \mathrm{~mL} \mathrm{~min}^{-1}$ for the sample and eluent solutions.

\section{Effect of Foreign Ions}

Matrix effects are the main problem in the atomic absorption spectrometry determination of metals in highly saline samples (31-37). The

\section{Atomic Spectroscopy \\ 1 Vol. 35(4), July/August 2014}

effect of some cations, anions, and some IA and IIA group metals on the recovery of the analytes was investigated using model solutions containing $20 \mu \mathrm{g}$ lead and $10 \mu \mathrm{g}$ cobalt and each foreign ion separately. The results are presented in Table II. The amount of each species can be considered as a tolerable limit because the deviation found in the absorbance was less than 5\% (37-41). The metal ions were almost quantitatively recovered in the presence of the interfering ions. The level of foreign ions in the analyzed fruit samples was below the levels listed in Table II, which means that the presented procedure can be used for these types of samples.

\section{TABLE II}

Effect of Foreign Ions

(Model solutions containing $10 \mu \mathrm{g}$ cobalt and $20 \mu \mathrm{g}$ lead, final volume at $10 \mathrm{~mL}$ )

\begin{tabular}{|c|c|c|c|c|}
\hline \multirow{2}{*}{$\begin{array}{l}\text { Foreign } \\
\text { Ions }\end{array}$} & \multirow[t]{2}{*}{ Added } & \multirow{2}{*}{$\begin{array}{l}\text { Concentration } \\
\left(\mu \mathrm{g} \mathrm{mL} L^{-1}\right)\end{array}$} & \multicolumn{2}{|c|}{ (\%) Recovery } \\
\hline & & & Cobalt & Lead \\
\hline $\mathrm{Ca}^{+}$ & $\mathrm{CaCl}_{2}$ & 3000 & 94.4 & 90.9 \\
\hline $\mathrm{Mg}^{+}$ & $\mathrm{Mg}\left(\mathrm{NO}_{3}\right)_{2}$ & 3000 & 94.5 & 95.5 \\
\hline $\mathrm{Na}^{+}$ & $\mathrm{NaCl}$ & 2000 & 83.3 & 100 \\
\hline $\mathrm{K}^{+}$ & $\mathrm{KCl}$ & 2500 & 100.0 & 90.9 \\
\hline $\mathrm{PO}_{4}{ }^{3-}$ & $\mathrm{Na}_{3} \mathrm{PO}_{4} \cdot 12 \mathrm{H}_{2} \mathrm{O}$ & 1000 & 94.4 & 95.5 \\
\hline $\mathrm{NO}_{3}^{-}$ & $\mathrm{KNO}_{3}$ & 2000 & 100.0 & 100 \\
\hline $\mathrm{SO}_{4}^{2-}$ & $\mathrm{Na}_{2} \mathrm{SO}_{4}$ & 2000 & 94.4 & 90.9 \\
\hline $\mathrm{Pb}^{2+}$ & $\mathrm{Pb}\left(\mathrm{NO}_{3}\right)_{2}$ & 25 & 100.0 & 95.5 \\
\hline $\mathrm{Fe}^{3+}$ & $\mathrm{Fe}\left(\mathrm{NO}_{3}\right)_{3} \cdot 9 \mathrm{H}_{2} \mathrm{O}$ & 25 & 94.4 & 90.9 \\
\hline $\mathrm{Zn}^{2+}$ & $\mathrm{Zn}\left(\mathrm{NO}_{3}\right)_{2}$ & 25 & 100.0 & 90.9 \\
\hline
\end{tabular}

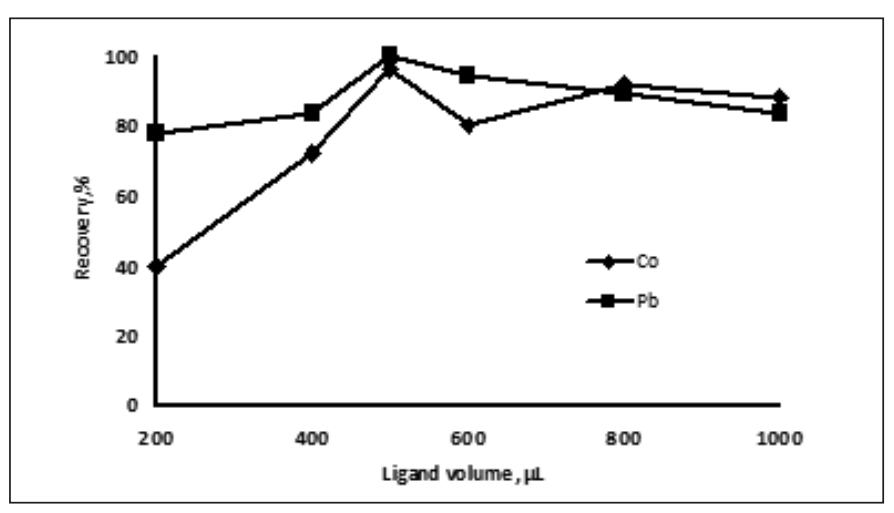

Fig. 2. Effect of the ligand volume on the extraction efficiency of cobalt and lead.

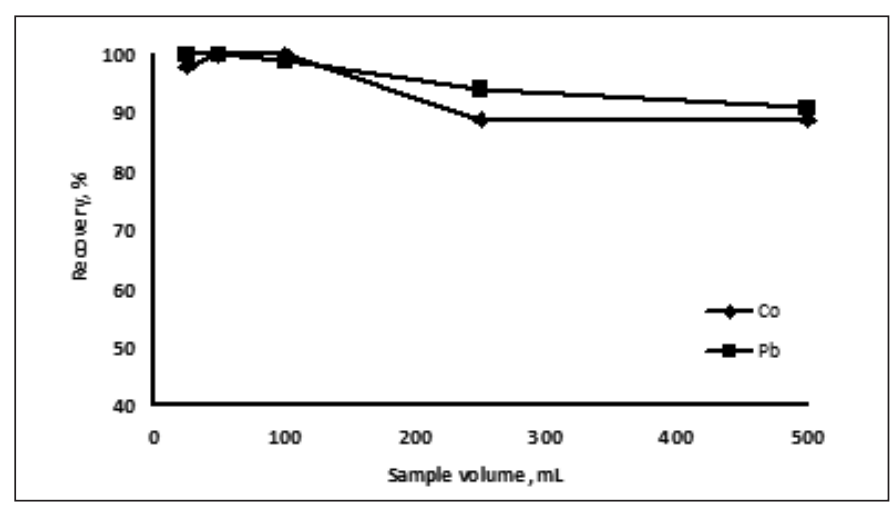

Fig. 3. Effect of the sample volume on recovery values of cobalt and lead. 


\section{Analytical Performance}

In order to estimate the applicability of the SPE method under optimum experimental conditions, the calibration curves were observed as linear and the concentrations ranged from $0.5-4.0 \mu \mathrm{g} \mathrm{mL}^{-1}$ $\left(\mathrm{R}^{2}=0.9997\right)$ for Co (Figure 4) and 1-10 $\mu \mathrm{g} \mathrm{mL}^{-1}\left(\mathrm{R}^{2}=0.9994\right)$ for $\mathrm{Pb}$ (Figure 5). The limit of detection (LOD), based on three times the standard deviation of 10 measurements of a reagent blank and $m$ as the slope of the calibration graph divided by the preconcentration factor, was $4.4 \mu \mathrm{g} \mathrm{L}^{-1}$ for Co and $1.04 \mu \mathrm{g} \mathrm{L}^{-1}$ for $\mathrm{Pb}$.

Validation of the method was checked by analyzing the standard reference material (SRM) NIST-1515 Apple Leaves. The results listed in Table III show that there was no significant difference between the results obtained in this study of $0.088 \mathrm{mg} \mathrm{Kg}^{-1}$ for Co and $0.482 \mathrm{mg}$ $\mathrm{Kg}^{-1}$ for $\mathrm{Pb}$ and the certified values of $0.09 \mathrm{mg} \mathrm{Kg}^{-1}$ for Co and 102.6

TABLE III

Determination of $\mathrm{Co}$ and $\mathrm{Pb}$ in NIST 1515 Apple Leaves (mg Kg-1)

\begin{tabular}{cccc}
\hline $\begin{array}{c}\text { Ele- } \\
\text { ment }\end{array}$ & $\begin{array}{c}\text { Experimental } \\
\text { Value } \\
(\mathrm{x} \pm \mathrm{ts} / \mathrm{n})^{\mathrm{a}}\end{array}$ & $\begin{array}{c}\text { Certi- } \\
\text { fied } \\
\text { Value }\end{array}$ & $\begin{array}{c}\text { Recov- } \\
\text { ery } \\
(\%)\end{array}$ \\
\hline $\mathrm{Co}$ & $0.088 \pm 0.003$ & 0.09 & 97.8 \\
$\mathrm{~Pb}$ & $0.482 \pm 0.019$ & 0.47 & 102.6 \\
\hline
\end{tabular}

${ }^{\mathrm{a}} \mathrm{x}=$ mean, $\mathrm{t}=\mathrm{t}$ value, $\mathrm{s}=$ standard deviation, $\mathrm{n}=$ number of experiments) $\mathrm{mg} \mathrm{Kg}^{-1}$ for $\mathrm{Pb}$. Addition/recovery tests were also performed. The results in Table IV verify that the proposed method is selective for the determination of cobalt and lead in real apple samples.

\section{Application of Method to Fruit Samples from Turkey}

The presented method was applied to the determination of cobalt and lead concentrations in some fruit samples purchased at local markets in Kayseri, Turkey. The cobalt and lead concentrations (listed in Table $\mathrm{V}$ ) ranged from 0.08-0.29 $\mathrm{mg} \mathrm{Kg}^{-1}$ and 0.20-0.56 $\mathrm{mg} \mathrm{Kg}^{-1}$, respectively. The highest concentration of cobalt was found in apricot at $0.29 \pm 0.01 \mathrm{mg} \mathrm{Kg}^{-1}$ and lead was highest in apple at $0.56 \pm 0.01 \mathrm{mg} \mathrm{Kg}^{-1}$. The lowest concentration of cobalt was found in banana at $0.08 \pm 0.01 \mathrm{mg} \mathrm{Kg}^{-1}$ and the lowest concentration of lead was found in kiwi at $0.20 \pm 0.01 \mathrm{mg} \mathrm{Kg}^{-1}$ ).

TABLE IV

Addition/Recovery Studies of $\mathrm{Co}$ and $\mathrm{Pb}$ in Real Apple Samples $\left(\mu \mathrm{g} \mathrm{g}^{-1}\right)$

\begin{tabular}{lccr}
\hline Element & Added & $\begin{array}{c}\text { Observed Concentration } \\
\text { of the Sample plus Spike }\end{array}$ & (\%) Recovery \\
\hline Cobalt & 0.0 & $0.15 \pm 0.007$ & - \\
& 2.0 & $2.16 \pm 0.06$ & 100.5 \\
& 4.0 & $4.14 \pm 0.13$ & 99.8 \\
Lead & 6.0 & $6.09 \pm 0.21$ & 99.0 \\
& 0.0 & $0.56 \pm 0.02$ & - \\
& 2.0 & $2.50 \pm 0.06$ & 97.0 \\
& 4.0 & $4.57 \pm 0.15$ & 100.0 \\
& 6.0 & $6.45 \pm 0.25$ & 98.1 \\
\hline
\end{tabular}

TABLE V

Determination of $\mathrm{Co}$ and $\mathrm{Pb}$ in Fruit Samples $\left(\mathrm{mg} \mathrm{Kg}^{-1}\right)(\mathrm{n}=4)$

\begin{tabular}{ccc}
\hline Fruit Samples & Co & $\mathrm{Pb}$ \\
\hline Apple & $0.12 \pm 0.01$ & $0.56 \pm 0.01$ \\
Kiwi & $0.16 \pm 0.01$ & $0.20 \pm 0.01$ \\
Apricot & $0.29 \pm 0.01$ & $0.52 \pm 0.01$ \\
Banana & $0.08 \pm 0.01$ & $0.37 \pm 0.02$ \\
Cherry & $0.22 \pm 0.01$ & $0.35 \pm 0.01$ \\
Grapes & $0.09 \pm 0.01$ & $0.34 \pm 0.01$ \\
Strawberry & $0.24 \pm 0.01$ & $0.54 \pm 0.01$
\end{tabular}

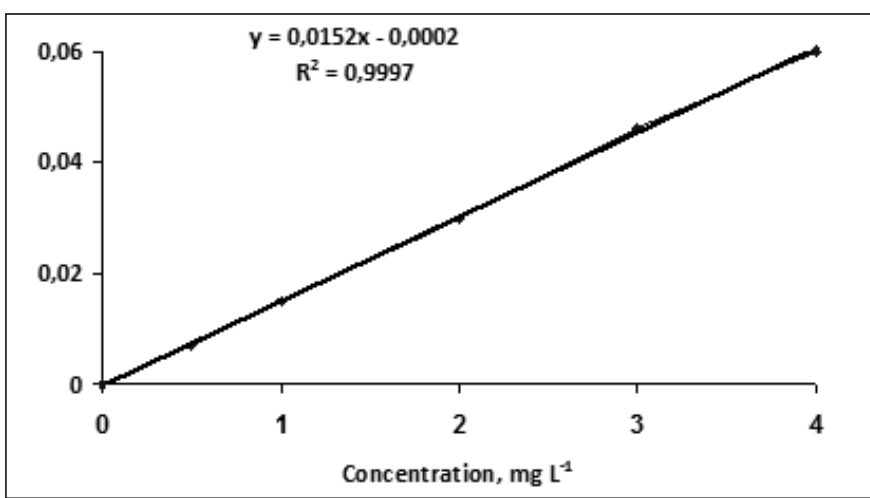

Fig. 4. Calibration curve for cobalt.

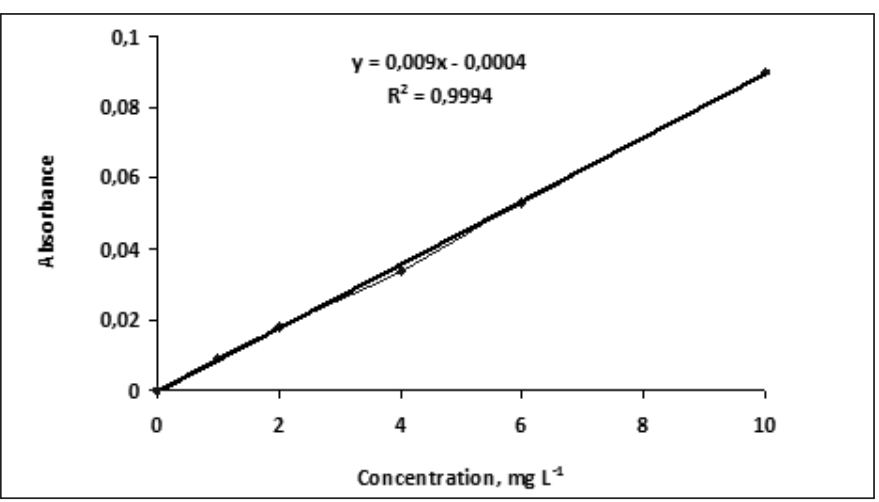

Fig. 5. Calibration curve for lead. 


\section{CONCLUSION}

A solid phase extraction procedure (SPE) was developed based on the separation and preconcentration of cobalt and lead as TAN chelates on diethylamine-modified phosphorus-containing polymer (DPCP). The samples were analyzed by FAAS which was found to be an efficient method for the sensitive determination of cobalt and lead in fruit samples. The preconcentration factor of the SPE technique was improved 10-fold. This method proved to be simple, precise, accurate, and inexpensive. The detection limits (LOD) were $4.4 \mu \mathrm{g} \mathrm{L}^{-1}$ for Co and $1.04 \mu \mathrm{g} \mathrm{L}^{-1}$ for $\mathrm{Pb}$. The adsorbent was used for more than 50 subsequent preconcentration cycles without loss in its sorption behavior.

\section{ACKNOWLEDGMENT}

Nusrat Jalbani is grateful to the Scientific and Technological Research Council of Turkey (TUBITAK) for the "2216 Research Fellowship Programme for Foreign Citizens" and financial support. The authors also thank Mr. Erkan Yilmaz for his help.

Received September 14, 2013.

\section{REFERENCES}

1. M. Tuzen, E. Sesli, and M. Soylak. Food Cont. 18, 806 (2007).

2. M. Tuzen, S.Silici, D. Mendil, and M. Soylak, Food Chem. 103, 325 (2007).

3. M. Soylak, O. Turkoglu, J. Trace Microprobe Tech. 17, 209 (1999).

4. A. Duran, M. Tuzen, and M. Soylak, Int. J. Food Sci. and Nutr. 59, 581 (2008).

5. M. Tuzen, M. Soylak, D. Citak, H.S. Ferreira, M.G.A. Korn, and M.A. Bezerra, J. Hazard. Mater. 162, 1041 (2009).
6. I. Narin, M. Soylak, K. Kayakirilmaz, L. Elci, and M. Dogan, Anal. Lett. 36, 641 (2003).

7. S.G. Ozean, N. Satiroglu, and M. Soylak, J. Food Chem. Toxicol. 48, 2401 (2010).

8. Z. Parveen, M. I. Khuhro, and N. Rafiq, B. Environ. Contam. Toxicol. 71, 1260 (2003).

9. S. Baytak and A.R. Turker, Talanta 65 , 938 (2005).

10. C.O.B. Okoye, Int. J. Environ. Stud. 58, 501 (2001).

11. E.P. Nardi, F. S. Evangelista, L. Tormen, T. D. Saint Pierre, A. J. Curtius, and S.S. de Souza, Food Chem. 112, 727 (2009).

12. R. Khani, F. Shemirani, and B. Majidi, Desalination 266, 238 (2011).

13. P.C. Aleixo, D.S. Junior, A.C. Tomazelli, I.A. Rufini, H. Berndt, and F.J. Krug, Anal. Chim. Acta 512, 329 (2004).

14. N. Jalbani, T.G. Kazi, N. Kazi, M.K Jamali, and M.B. Arain, Ren. Fail. 30, 737 (2008).

15. I. Narin and M. Soylak, Anal. Chim. Acta. 493, 205 (2003)

16. M. Karimi, F. Aboufazeli, H.R.L.Z. Zhad, O. Sadeghi, and E. Najafi, Polish J. Chem. Technology 15, 86 (2013).

17. I. Narin, M. Soylak, L. Elci, and M. Dogan, Anal. Lett. 34, 1935 (2001).

18. T. Shamspur, M.H. Mashhadizadeh, and I. Sheikhshoaie, J. Anal. At. Spectrom. 18, 1407 (2003).

19. E. Melek, M. Tuzen, and M. Soylak, Anal. Chim. Acta 578, 213 (2006)

20. S.Z. Mohammadi, D. Afzali, and D. Pourtalebi, Cent. Eur. J. Chem. 8, 662 (2010).

21. V. Camel, Spectrochim. Acta Part B. 58, 1177 (2003).

22. M. Tuzen, K.O. Saygi, and M. Soylak, J. Hazard. Mater. 152, 632 (2008).

23. R. M. Alosmanov, A. A. Azizov, and A. M. Magerramov, Russ. J. Gen. Chem. 81, 1477 (2011).

24. M. Soylak, I. Narin, M. D. A. Bezerra, and S.L.C. Ferreira, Talanta 65, 895 (2005).

\section{Atomic \\ Mpectroscopy \\ $\bigcirc$ Vol. 35(4), July/August 2014}

25. M. Soylak, L. Elci, and M. Dogan, Anal. Lett. 33, 513 (2000).

26. S.P. Zhou, C.Q. Duan, H.C. Liu, and Q.F. Hu, Spectrosc. Spectral Anal. 25, 1667 (2005).

27. M. Soylak, I. Narin, and M. Dogan, Anal. Lett. 30, 2801 (1997).

28. A. Goswami and A.K. Singh, Anal Bioanal. Chem. 374, 554 (2002)

29. M. Ghaedi, F. Ahmadi, and M. Soylak, Ann. Chim. (Rome) 97, 277 (2007).

30. S.I. Hasegawa, Materials Transactions 49, 2054 (2008).

31. M. Ghaedi, A. Rezakhani, S. Khodadoust, K. Niknam, and M. Soylak, Scientific World Journal, Article ID 764195, 1-9 (2012).

32. Y. Sohrin, S. Urushihara, S. Nakatsuka, T. Kono, E.Higo, T. Minami, K. Norisuye, and S. Umetani, Anal. Chem. 80, 6267 (2008).

33. M. Tuzen and M. Soylak, Polish J. Environ. Studies 15, 915 (2006).

34. M. Soylak, L. Elci, and M. Dogan, J. Trace Microprobe Tech. 17, 149 (1999).

35. J.-G. Han, J.-Y. Lee, K.-K. Hong, J.-Y. Lee, Y.-W Kim, and S.-M Hong, J. Material Cycles Waste Management 12, 227 (2010).

36. G. Kaya, I. Akdeniz, and M. Yaman, At. Spectrosc. 29, 106 (2008)

37. M. Soylak, L. Elci, and M. Dogan, Fresenius Environ. Bull. 5, 148 (1996).

38. O. Yildiz, D. Citak, M. Tuzen, and M. Soylak, J. Food Chem. Toxicol. 49, 458 (2011).

39. M. Soylak, Anal. Lett. 37, 1203 (2004).

40. M. Ghaedi, M.R. Fathi, F. Marahel, and F. Ahmadi, Fresenius Environ. Bull. 14, 1158 (2005)

41. M. Tuzen, K.O. Saygi, and M. Soylak, .J. Hazard. Mater. 156, 591 (2008). 